\title{
Evaluation of Board of Directors in Public Enterprises of Kosovo
}

\author{
Metë Beqiraj ${ }^{1}$, Magdalena Bregasi ${ }^{2}$
}

\begin{abstract}
Public Enterprises (PE) in Kosovo were incorporated in December 2005 and corporate governance (CG) was adopted for the first time. CG is a new concept in Kosovo and is currently under the process of development and improvement. PE's in Kosovo are owned 100\% by the government. CG in PE poses a significant challenge in many economies because of its complex nature. The purpose of this research is to shed some light on the conditions that are needed for ensuring the effectiveness of the Board of Directors (BD) of PE. Composition of the Board of PE plays a key role in the CG. Strengthening of BD to exercise effective monitoring is a difficult challenge for PE. PE's in Kosovo are characterized by a lack of law enforcement and political interference from the central bodies of government. The basic hypothesis is that non-professional boards that are influenced by political interference have a negative impact upon the performance of the PE. Methodology: This research was conducted using primary data (surveys and interviews) and secondary data (annual reports, financial statements, regulatory reports and PMUPE). The results of the research will identify priorities of the reforms that lead toward improvement of CG and economic performance.
\end{abstract}

Keywords: corporate governance, evaluation, public enterprises.

\section{Introduction}

The purpose of this research is to bring to light conditions that are necessary for ensuring effectiveness of Board of Directors (BD) of PE. The objective of this paper is to use this research as an important input for a strategy towards good corporate governance and how to improve corporate governance in PE of Kosovo in light of the OECD guidelines (2005) and EU standards, and to inform stakeholders on the principles and modern practices regarding the corporate governance (CG). CG in PE poses a significant challenge in many economies because of its complex nature. $\mathrm{CG}$ in $\mathrm{PE}$ is a critical for ensuring its positive contribution to economic efficiency and overall competitiveness of a country. Experience has also shown that good governance of stateowned enterprises is an important prerequisite for effective privatization, for it makes these enterprises more attractive to prospective buyers and increase their market value. Best practices of CG can help companies in Kosovo increase efficiency, protect the rights of shareholders and improve their access to international capital markets. Challenges of public companies are more difficult than those of private companies. If the main goal of private companies is the profit maximization, public sector companies 
should pursue trade business objectives. The problem of agency, which plays an important role in the theory of government, is much more visible and tangible in private companies in comparison to public sector.

Based on the principles of the OECD for CG, state-owned companies should focus on policies that ensure good governance of these companies. Empirical studies maintain that companies with a good CG standard are being valued higher in financial markets (McKinsey, 2002). "Good CG helps to bridge the gap between the interests of those who manage a company and the shareholders who own it, increasing thus the confidence of investors and making it easier for companies to raise equity capital and finances in the investment process. Good CG also helps to ensure that a company engages and abides its own laws and creates a value in establishing relationships with stakeholders, including employees and creditors "(OECD, 2013).

Many studies have come to conclusions that the problems of the CG have emerged because of the conflict of interest between the parties involved in the CG (Fama and Jensen, 1983). The CG topic is becoming increasingly important on a global scale after the Asian financial crisis in 1997, Russia in 1998 and bankruptcy and scandals in the US during 2001 and 2002 and the outbreak of the global financial crisis that engulfed the economy in 2008 (GCGF, 2012). In response to these scandals, Organization for Economic Cooperation and Development (OECD) developed a set of standards and guidelines on CG. OECD principles on CG were accepted in 1999 and were reviewed in 2004 (OECD, 2004). The principles of the OECD (OECD, 2004) are internationally recognized, and treat all spectrum of CG. OECD principles have also served as a reference point for the development of a growing number of CG standards in different countries. After infamous scandals, many academics, experts and professional organizations presented their recommendations (Becht, 2005). Experience has also shown that the issue of salaries of managers and their relation to performance was at the center of debates and CG literature (Baker, 1988) and (Jensen and Murphy, 1990). OECD has developed guidelines on the CG state-owned enterprises, designed to meet OECD principles on CG (OECD, 2005). OECD has been asked to encourage implementation of its principles on $C G$ in its non-members, through round tables, as were organized in Asia, Latin America, Russia, Eurasia and Eastern Europe (OECD, 2003). PE in Kosovo are owned by government (Law No. 03 / L-087, 2008), and might be the subject to guidelines (OECD, 2005). Various authors define the concept of the CG in different ways. Universal accepted definition of the term is derived from Sir Adrian Cadbury's report on CG, as "system by which the company is directed and controlled" (Cadbury, 1992).

Promoting CG has become a global movement developing wide array of standards, codes and criteria for evaluation. This research is intended to be a baseline for creation of a landmark and is expected to contribute to increasing awareness and knowledge at CG in Kosovo. The Government of Kosovo, also supported by international institutions operating in Kosovo, has shown a commitment to improve the CG. The Government of Kosovo among other affairs has adopted the following laws: Law on Commercial Associations no. 02 / L-123 (2007); Law on Public Enterprises no. 03 / L-087 (LPE, 2008), which was later amended, Law no. 04 / L-111 (2012). Policy and Monitoring Unit 
of the PE (PMUPE), Code of Ethics and Corporate Governance for PE (PMUPE, 2010) were established, etc. Yet the challenge is the implementation of it in practice.

\section{Corporate Governance in Public Enterprises (PE)}

Public enterprises (PE) play an important role in most countries of the world and often have a dominant role in the utilities, telecommunications, transport, etc. In many OECD countries, public enterprises still have an important role in production and employment. Based on the OECD guidelines, the term "public enterprises" refers to enterprises in which the state has a significant control, through full ownership, major or minor ownership. In most developing countries, these enterprises are most dominant sector of the economy in terms of output and employment. Therefore, the operation of PE can have a great influence on economic efficiency and the competitiveness of the country as a whole. PE's are often subject to politically motivated and excessive government intervention.

It is therefore important to develop appropriate mechanisms in order to enable these companies to have a leadership similar to that of private companies in a competitive environment.

For that reason, the OECD has developed guidelines on CG of PE, designed to meet the OECD principles on the CG (OECD, 2005). Based on the OECD principles for CG, state-owned companies should focus on policies that ensure good governance of these companies. So the PE in Kosovo are similar to state-owned enterprises in other market economies and may therefore be subject to the OECD guidelines for CG StateOwned Enterprises (2005). PE's in Kosovo were incorporated in December 2005 wherein CG was adopted for the first time. Good practice of CG will prosper in the market, it will bring additional capital, it will create competitive advantages, and will bring changes to the world and significant economic development. Furthermore, CG, in theory and practice, is associated with companies in which government is clearly separate from the owners, according to the OECD definition.

CG is a set of processes, rules, laws, policies and institutions that determine how a company shall be governed, administered or controlled. It also includes the relationships of many stakeholders involved in corporate governance. Therefore CG has to do with relations between the different stakeholders involved (participating parties) and goals on how the company shall be governed. The main stakeholders are: shareholders, management and board of directors. Other parties include: employees, suppliers, customers, banks and other lenders, regulators, government, environment and wider community. CG is used to monitor whether results are in compliance with plans and motivate the organization to be fully informed in order to maintain or change the activity of the organization.

PE's in Kosovo provide electricity supply, telecommunication services, rail, airport terminal, central heating, irrigation, water supply and sanitation, mainly at the municipal level. These PE's have major impact on the functioning of other economic sectors, as providers of key inputs. They also affect directly the welfare of the citizens. Whatever their improvement would be, it would have direct and strong effect on the economy and on Kosovo society. The reform and restructuring of public enterprises addresses the 
problem of CG and align procedures of good corporate governance with international standards, such as those established by the OECD for the enterprises. PE should become market-oriented company in which private investors, especially in the free and common market of the region, participate. Based on Law on PE (Law No. 03 / L-087) Article 3.1, all central PE's are 100\% owned by government. According to the law, the government is obliged to supervise the management of these enterprises and to report to Parliament on an annual basis. Under the law, the government is mandated to initiate the introduction of the private sector in these companies (through concessions or partial or complete privatization of particular sections of $\mathrm{PE}$ ).

\section{Board of Directors}

Law on PE (Law No. 03 / L-087) defines the model with a board-level (one-tier board), known as the Anglo-American model. According to the Law on PEs Article 15, paragraph 15.1 the Board of Directors (BD) of a PE shall composed of five or seven directors. All directors, except one, shall be appointed by the government and each such elected director shall have a 3-year term. The other director shall be Executive Director (ED) of PE and elected by the Board of PE in accordance with Article 21 of the aforementioned Law. According to the Law on PE, Article 17, paragraph 17.2 all directors except the ED shall be independent. Under this law, PE has 82.5\% independent directors and 17.5\% ED. Article 37, paragraph 37.1 provides the establishment of Policy and Monitoring Unit of the PE (PMUPE) within the Ministry in order to support the Minister and the Government in exercising the responsibilities for PE which were granted to them by this law. PMUPE is responsible for organizing the training for directors of $\mathrm{PE}$, and the findings of our research show that such a training is organized every year, in cooperation with the International Development Agency of the United States (USAID) and the International Finance Corporation (IFC).

The manner and criteria for selection of directors are defined by the same law. Some of these criteria are professional adaptability, political impartiality, avoid conflict of interest and not being prosecuted. So the issue of appointing directors lies in the abiding the law, in practice it turns out that the selection of the list of candidates that are voted at the Assembly of Kosovo is non-transparent and not politically influenced. Although stipulated by law, the evaluation of the professionalism of $\mathrm{BD}$ of $\mathrm{PE}$ still remains problematic because of the lack of transparency upon the process of nomination of the board.

The findings show that no data for the professional and biography of BD members are published, but we indirectly learn that all members of BD have a university degree. Referring to the law, the mandate of all BD's has expired in December 2011 and even after the announcement of two vacancies in 2012 no new board was elected due to political interference. Election of Board of PE remains one of the most contested issues by opposition, non-governmental organizations and civil society. Criticism had to do with lack of transparency, political appointments, professionalism in boards and high fees. The research revealed that PE boards are also used as a sector which embraces militants of political parties. Hiring of party militants enables political parties to have more impact on these companies for pushing forward their policies. It also provides 
more opportunities for employing more politicized people at the lowest ranks of the company.

In the past two years, BD's were incomplete and non-functional. The situation at the beginning of 2015 shows that only two PE's had BD chosen, whereas other PE's had no boards. According to political agreement between the parties in power, in January 2015 a new vacancy for $\mathrm{BD}$ of $\mathrm{PE}$ was announced, yet no selection took place.

\section{Evaluation of PE Performance}

PMUPE was established in 2009 to support the government in its responsibilities on $\mathrm{PE}$ and is responsible for the supervision and monitoring of $\mathrm{BD}$. This unit currently operates with a staff of seven people, whereas according to the government's decision of 2008, twelve (12) employees were supposed to support the unit.

According to Article 8 of the Law on PE, the shareholder is required to report annually to Parliament on the performance at PE sector. PMUPE has a legal liability to monitor and report on the PE performance, individually and collectively. PMUPE in its reporting has focused on the following:

- Operational Performance (results achieved, efficiency, quality of service),

- Financial performance (turnover achieved, cost efficiency, profitability)

- CG (monitoring the work of the boards, accountability, business planning),

- Future prospect (market changes, investment, risks).

The report summarizes the operational and financial results of PE for 2010 - 2012. The report provides a clear view of the performance and perspectives in the PE sector before MPs and the public, the issues facing the current level of services, as well as subsequent developments to improve the CG in these sectors. This report presents the performance at the PE sector from the perspective of shareholders. The 2012 report is supported by international consultants sponsored by SDC (Swiss Economic Cooperation). The report presents a careful review of the verified data from the PE reports, the independent regulators, and financial external auditors. The same data then were analyzed and at the end recommendations for improvement of the performance of the PE were given (PMUPE, July, 2013 Annual Performance Report of PE 2012), Table 1. 
Table 1: Financial performance of PE

\begin{tabular}{|c|c|c|c|c|c|c|}
\hline Central Publicly- & \multicolumn{3}{|c|}{2011} & \multicolumn{3}{|c|}{2012} \\
\hline & $\begin{array}{l}\text { Revenues } \\
1 \\
(000 €)\end{array}$ & $\begin{array}{l}\text { Costs }^{2} \\
(000 €)\end{array}$ & $\begin{array}{l}\text { Profit/Loss } \\
3 \\
(000 €)\end{array}$ & $\begin{array}{l}\text { Revenue } \\
\text { s (000€) }\end{array}$ & $\begin{array}{l}\text { Costs } \\
(000 €)\end{array}$ & $\begin{array}{l}\text { Profit/Los } \\
\text { s } \\
(000 €)\end{array}$ \\
\hline PIA “Adem Jashari” & 8,958 & $-8,562$ & 396 & 2,593 & $-4,533$ & $-1,940$ \\
\hline KEK & 257,496 & $\begin{array}{l}- \\
240,97 \\
9\end{array}$ & 16,517 & 269,976 & $\begin{array}{l}254,61 \\
6\end{array}$ & 15,360 \\
\hline KOSTT & 18,792 & $-17,509$ & 1,283 & 21,524 & $-18,735$ & 2,789 \\
\hline PTK & 164,297 & $\begin{array}{l}- \\
118,18 \\
1\end{array}$ & 46,116 & 149,617 & $\begin{array}{l}- \\
111,27 \\
9\end{array}$ & 38,338 \\
\hline PK & - & - & - & 4,402 & $-5,571$ & $-1,169$ \\
\hline Infrakos & 1,337 & $-1,420$ & -83 & 3,163 & $-3,215$ & -52 \\
\hline Trainkos & 2,364 & $-2,016$ & 348 & 5,053 & $-5,523$ & -470 \\
\hline KLMC & 1,187 & $-2,098$ & -911 & 1,293 & $-1,913$ & -620 \\
\hline Iber Lepenc & 3,810 & $-7,800$ & $-3,990$ & 3,808 & $-7,978$ & $-4,170$ \\
\hline RWC Drini i Bardhë & 227 & -244 & -17 & 303 & -337 & -34 \\
\hline $\begin{array}{ll}\text { RWC } & \text { Radoniqi- } \\
\text { Dukagjini } & \end{array}$ & 887 & -885 & 2 & 891 & -880 & 11 \\
\hline RWC Prishtina & 12,941 & $-13,265$ & -324 & 13,514 & $-13,341$ & 173 \\
\hline RWC Mitrovica & 3,775 & $-3,713$ & 62 & 3,875 & $-3,282$ & 593 \\
\hline RWC Hidromorava & 1,716 & $-2,068$ & -352 & 1,882 & $-1,915$ & -33 \\
\hline RWC Hidrodrini & 3,067 & $-3,220$ & -153 & 3,578 & $-3,592$ & -14 \\
\hline RWC Radoniqi & 2,924 & 3,601 & -677 & 3,233 & $-3,790$ & -557 \\
\hline $\begin{array}{l}\text { RWC Hidroregjioni } \\
\text { Jugor }\end{array}$ & 3,579 & $-4,075$ & -496 & 4,069 & $-4,417$ & -348 \\
\hline
\end{tabular}

Source: PMUPE (July, 2013), PE Financial Performance, according to External Audit Report.

The table shows that in 2012, despite a slight progress compared with the previous year, but not at the desired level, in general, all PE operate on loss and do not provide quality services to people.

\section{Evaluating the effectiveness of the performance of the Board of PE}

PMUPE based on Law, Article 28, and paragraph 28.3, has evaluated the effectiveness of the work of central PE for 2010 and published a report in November 2011.

The core elements for evaluating the performance of the Board of PE activities were as follows:

\footnotetext{
${ }^{1}$ Revenues include income and grants

2 Including depreciation, bad debts, etc.

3 Profit / Loss after taxes
} 
- Review of current activity of the PE;

- Review of operational efficiency indicators used by the management of PE, compared with the Business Plan (BP), approved by the Board;

- Review of the efficiency of the work of $\mathrm{BD}$, ability to make decisions in the interest of the company in respect of the legal and regulatory framework;

- Review and evaluate the performance of the board and audit committee (AC) regarding their responsibility to monitor the implementation of BP, approved by them, respecting the laws and the establishment of an internal control system that optimizes the most efficient use of resources, which allows storing them, as well as transparency and economic justification (for the best interests to the shareholder) in decision-making;

- Review the implementation of best practices to CG, referring to the Code of Ethics of the CG in PE, highlighting the obligation of reporting to the shareholder.

PMUPE supported by external consultants, after analyzing data on operational and financial performance and CG in PE, has evaluated the effectiveness of the performance of BD (2010/2011). According to the report, in Figure 1, we will provide data on the BD for 15 PE (by 2011 were 15 PE) that have fully, partially, or failed to fulfill all duties of loyalty to the shareholder (the government) (PMUPE, 2011).

Fig.1: BD who fulfilled, fully, partially, did not fulfill all, fiduciary duties (trusted) to the shareholder (government).

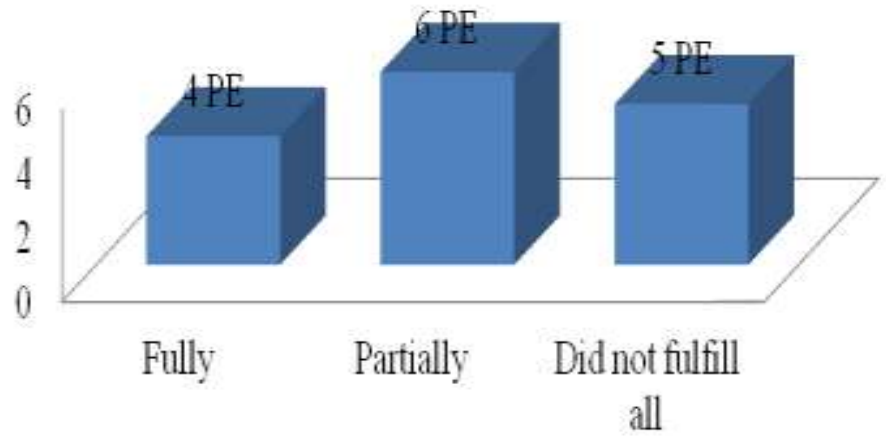

Source: Ministry of Economic Development, PMUPE, Evaluation of the effectiveness of BD of PE for 20102011.

As a result of the restructuring of $\mathrm{PE}$ and the implementation of property policies to state-owned PE, aiming to increase the quality of public service to the people of Kosovo, the restructuring initiated in previous years is a continuous process (PMUPE, 2013):

PMUPE (2012) in the latest evaluation of the effectiveness of the performance of the $\mathrm{BD}$ of PE after recent restructuring, currently there are $17 \mathrm{PE}$ 's, summarized BD's in the four groups as follows:

I. Group of BD that has fully fulfilled the duties of loyalty to the shareholder: In this group 4 PE's are classified: (RWC Prishtina, RWC Morava Hydro-Gjilan; Electricity 
Transmission, System and Market Operator -KOSTT; RWC Radoniqi- Dukagjin Gjakova).

II. Group of BD that performed its duties of loyalty to the shareholder: 5 PE's fell into this group: (RWC Hidrodrini-Peje; HK-Infrakos, RWC Southern Hydro - Prizren, Post of Kosovo (01.08-31.12.2012) and RWC Radoniqi- Gjakova).

III. Group of BD's that are fulfilling completely duties of loyalty to the shareholder: 4 PE's fell into this group: (PIA) - PIA "Adem Jashari"; HS Iber-Lepenc; KEK; Trainkos $\mathrm{KR})$.

IV. Group of BD that did not fulfill the duties of loyalty to the shareholder: 4 PE's fell into this group: (RWC Mitrovica Mitrovica, RWC Drini-Peje; Kosovo Landfill Management Company KLMC, Post and Telecommunications of Kosovo- PTK).

Figure 2: Evaluation of BD's that have fulfilled or failed to fulfill the duties of loyalty to the shareholder.

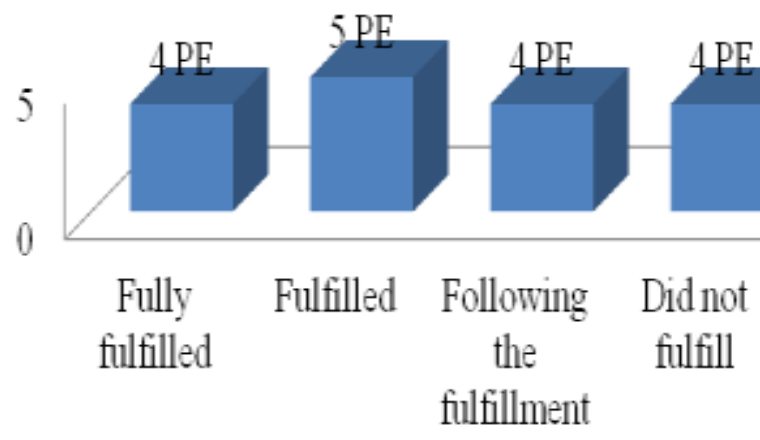

Source: PMUPE 2013. Evaluation of the effectiveness of the BD of PE for 2012 (July 2013).

Likewise, during evaluation, PMUPE managed to determine the effectiveness of the work of $\mathrm{BD}$, as a direct impact on the progress achieved by PE in accordance with the policies and strategies implemented to improve the performance of the CG, taking into account European standards and norms. Evaluation of boards is very important and European average rating was 75\% in 2011 (Heidrick \& Struggles, 2011, p. 29).

\section{Conclusion and recommendations}

Based on this research, we can draw conclusions that the state of corporate governance in Kosovo PE is gradually improving, but there is still ample room for improvement and expedite this process. Positive effects of greater transparency and greater public access to information on the operation of the PE should be reflected. On the other hand, PE's have generally done little to inform current investors and would-be 
ones, through their websites. Analysis of survey results among members of management and $\mathrm{BD}$ shows that $\mathrm{PE}$ at least formally implemented the relevant regulatory mechanisms in the administration, such as the existence of rules and restrictions on specific strategies and related decision-making. But situations where there might be conflict of interest among members of management with regards to PE, shareholders and transactions with related parties are less regulated.

As in other countries, in Kosovo effective governance of PE is a difficult and complex phenomenon. Research analysis point out that the government as a shareholder is not interested to improve the performance of PE and there is too much political interference at the appointment of directors and management. Political appointments of inexperienced and unqualified people at boards and management who are supported by certain political groups weaken the quality of the CG. CG in PE of Kosovo has made a progress over time but more efforts should be made and focus on enhancing the quality of the board of directors, whose members should be better informed about the company's operations, professionally trained and should have greater independence and be not subject to political influence, because strengthening the role of BD allows high efficiency and enhance the company's reputation. These results reflect that the concept of CG in Kosovo is in the beginning stage, it is evolving but it is not well understood or applied. The research results also show the need for raising awareness about the importance of the CG and its implementation. Remuneration of Board members must be linked to business performance and must be transparent. PMUPE is satisfied with the cooperation and reporting of BD. Remuneration of directors, based on government's decision, is fixed, but the bonuses should be transparent. Privatization of state-owned shares in certain PE has moved very slowly, which at the current level of their management and financial sustainability means relatively low level of corporate governance quality in PE in Kosovo. PE shares of $100 \%$ of the government are reflected in the composition of BD. Eventually BD and management are politically influenced by the government (a shareholder) and exert a positive and significant effect on employment, while they negatively affect the cost of the agency and the performance of the PE.

\section{References}

Baker, G., M. Jensen and K. Murphy (1988). Compensation and Incentives: Practice vs. Theory, The Journal of Finance, vol. 43, No. 3: 593-616.

Becht M., Bolton P. and Röell A., (2005). Corporate Governance and Controll. ECGI Finance Working Paper No. 02/2002, Updated August 2005.

Cadbury, Sir A. (1992), Report of the Committee on the Financial Aspects of Corporate Governance (Gee and Co., London).

Fama, E. \& Jensen, M., (1983a), Separation of ownership and control, Journal ofLaw and Economics 26, 301-325.

Global Corporate Governance Forum- IFC (GCGF- IFC, 2012), Corporate Governance Codes and Standards Practice Group Meeting, May 17-18.

Heidrick \& Struggles (2011), Europian Corporate Governance Report 2011: Challenging board performance. Jensen, M. \& Murphy K., (1990), Performance pay and top management incentives, Journal of Political Economy 98, 225-263. 
Ligji Nr. 03/L-087, Për Ndërmarrjet Publike, 13 qershor 2008, i ndryshuar me Ligjin Nr. 04/L-111, 30 Maj 2012.

Ligji Nr. 02/L-123, Për Shoqëritë Tregtare, 27 shtator 2007, i ndryshuar me Ligjin Nr. 04/L-006, 23 qershor 2011.

McKinsey \& Company (2002): Global Investor Opinion Survey: Key Findings, London. http://www. mckinsey.com/governance.

NJPMNP, (2011), Vlerësimi i BD të NP për vitin 2010, Nëntor 2011.

NJPMNP, (2013), Vlerësimi i efektivitetit të punës së BD të NP qendrore për vitin 2012.

NJPMNP, (2013). Raporti vjetor i performancës së NP, 2012.

OECD, 2013; Corporate Governance and Capital Markets in Eurasia: Two Decades of Reform, OECD, Paris, 2013.

OECD, (2005), Guidelines on the Corporate Governance of State-Owned Enterprises, Paris, 2005.

OECD, (2004), OECD Principles of Corporate Governance, Organization for Economic Cooperation and Development, Paris, 2004.

OECD (2003), White Paper on Corporate Governance in South East Europe, Paris: 